\title{
Analysis of Artifacts from a 2010 Surface Collection at the Pace McDonald Site (41AN51), a Probable Middle Caddo Mound Center in Anderson County, Texas
}

Timothy K. Perttula

Heritage Research Center, Stephen F. Austin State University

Mark Walters

Heritage Research Center, Stephen F. Austin State University

Bo Nelson

Heritage Research Center, Stephen F. Austin State University

Follow this and additional works at: https://scholarworks.sfasu.edu/ita

Part of the American Material Culture Commons, Archaeological Anthropology Commons, Environmental Studies Commons, Other American Studies Commons, Other Arts and Humanities Commons, Other History of Art, Architecture, and Archaeology Commons, and the United States History Commons

Tell us how this article helped you.

This Article is brought to you for free and open access by the Center for Regional Heritage Research at SFA ScholarWorks. It has been accepted for inclusion in Index of Texas Archaeology: Open Access Gray Literature from the Lone Star State by an authorized editor of SFA ScholarWorks. For more information, please contact cdsscholarworks@sfasu.edu. 


\section{Analysis of Artifacts from a 2010 Surface Collection at the Pace McDonald Site (41AN51), a Probable Middle Caddo Mound Center in Anderson County, Texas}

\section{Creative Commons License}

\section{(c) (1) \&}

This work is licensed under a Creative Commons Attribution-NonCommercial 4.0 International License 


\title{
Analysis of Artifacts from a 2010 Surface Collection at the Pace McDonald Site (41AN51), a Probable Middle Caddo Mound Center in Anderson County, Texas
}

\author{
Timothy K. Perttula, Mark Walters, and Bo Nelson
}

\section{INTRODUCTION AND SITE SETTING}

The Pace McDonald site (41AN51) is a prehistoric Caddo mound center on Mound Prairie Creek in Anderson County, Texas, in the upper Neches River Basin (Pearce and Jackson 1933; Newell and Krieger 1949; Story 2000; Thurmond 1978). With the permission of one of the landowners, Mr. Johnny Sanford, the Friends of Northeast Texas Archacology has initiated an archaeological research effort at the site in 2010, the first part of which was an April 2010 surlace reconnaissance of the Sanford lands at the site, and the surface collection of artifacts exposed there following shallow disking of several tracts within the known boundaries of the site. This article discusses the character of the artifacts collected in the spring 2010 work.

The purpose of this work at the Pace McDonald site is to learn more about the native history of this mound center-when it was occupied and used, and by which prehistoric Caddo group-and its intra-site spatial organization. Ultimately, we hope to be able to obtain site-specific archaeological information that can help us to better understand the site's place and role in the Caddo prehistory of this part of East Texas.

The site is situated on a large and relatively flat upland landform (420-430 feet amsl) not far north of Mound Prairie Creck, in central Anderson County, Texas, in the East Texas Pineywoods (Diggs et al. 2006). Mound Prairie Creek is a southward- and eastward-flowing tributary to the Neches River; the confluence of these two streams lies about $20 \mathrm{~km}$ to the east of the site. When the site was first visited and recorded in the 1930s, it was in a large cotton field (Pearce and Jackson 1933:2). In more recent years, it is in an improved pasture, and the site is apparently owned by several landowners, including the Texas Historical Commission.
The site is on an expanse of Elrose fine sandy loam, 1-3 percent slopes (Coffee 1975:17 and Sheet 34 ). This is a relatively fertile upland soil that "formed under a pine-hardwood forest in stratified marine and alluvial sediment high in glauconitic sandstone" (Coffee 1975:17 and Table 2). A typical profile of the Elrose fine sandy loam is a $25 \mathrm{~cm}$ thick A-horizon that ranges from reddish-brown to yellowish-red fine sandy loam developed atop a thick (ca. $165 \mathrm{~cm}$ ) Bt horizon composed of red, dark red, yellowish-red, or strong brown sandy clay loam and sandy loam. The underlying $\mathrm{C}$ horizon is a massive red loamy fine sand with an occasional fragment of glauconitic sandstonc.

Limited archaeological investigations at the Pace McDonald site since the 1930 s indicates that the site covers ca. 11 acres $\left(45,000 \mathrm{~m}^{2}\right)$ of the upland landform adjacent to Mound Prairic Creck. The site has two deliberately constructed prehistoric Caddo earthen mounds, a large and associated habitation area (including several midden areas) and surface scatters of ceramic and lithic artifacts, and probably at least one associated cemetery area (Figure 1). There are also a number of small depressions, with an average depth of $30-60 \mathrm{~cm}$, visible on the landform that may represent borrow pits for sediments used by the Caddo to build the two earthen mounds (Mounds No. 1 and No. 2) that were constructed over special purpose structures with significant accumulations of ash (Perttula 2011). In 1978, the depressions ranged from $6.1-25 \mathrm{~m}$ in diameter (Thurmond 1978).

Analysis of the artifacts from the site in the collections at the Texas Archeological Research Laboratory at The University of Texas at Austin (TARL) suggests that the Pace McDonald Caddo occupation probably hegan in the 12th century A.D. and continued well into the 14 th century A.D. Temporally speaking then, Perttula (2011) views the Pace McDonald site as a Early to Middle Caddo period mound site whose occupation 


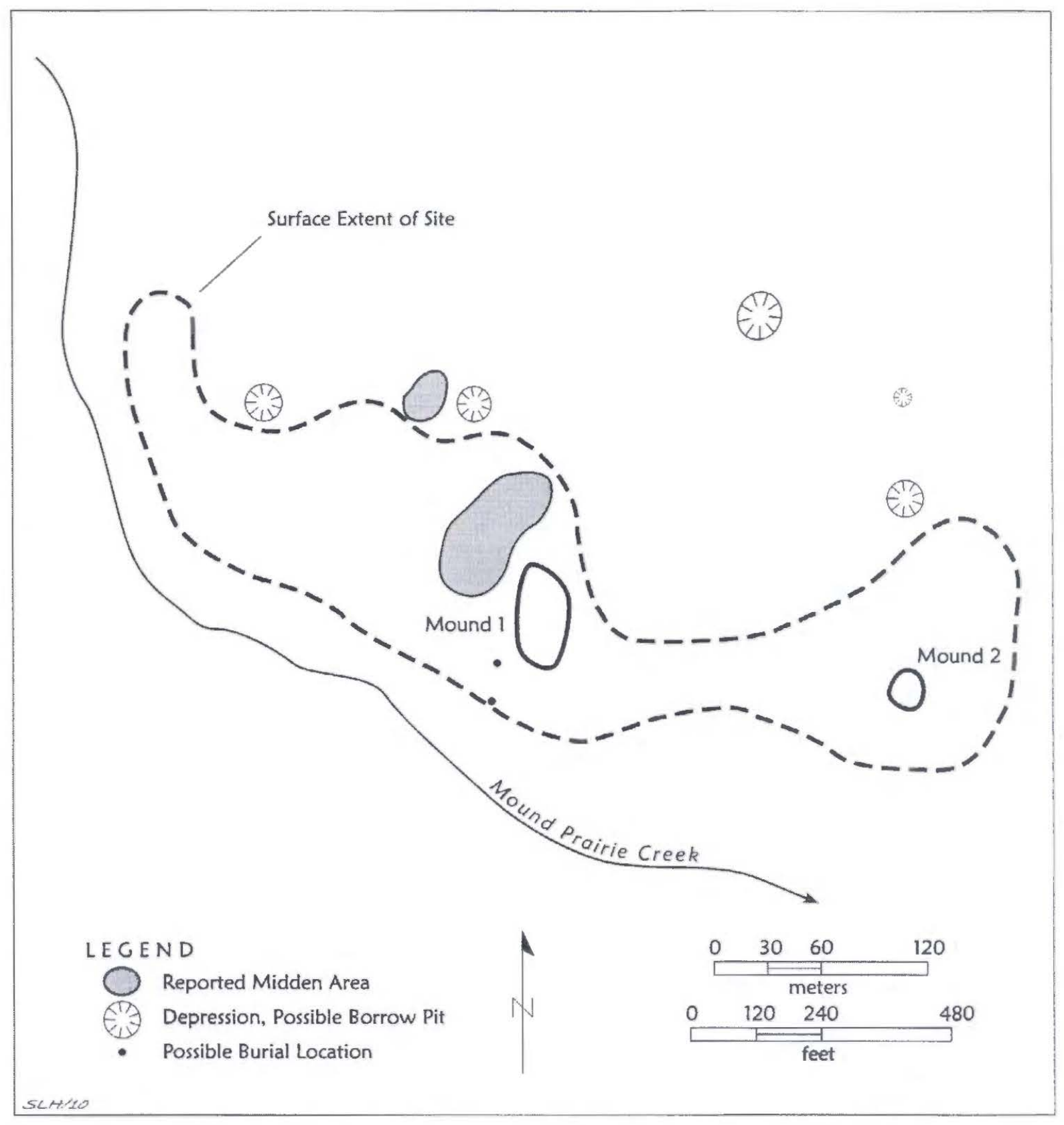

Figure 1. Map of the Pace McDonald site (41AN51), based on a 1978 sketch map by Ulrich Kleinschmidt and Pete Thurmond, and other information in the Texas Archcological Research Laboratory, The University of Texas at Austin files.

began and overlapped with that of the George C. Davis mound center after ca. A.D. 1100 , but apparently the use of the Pace McDonald site as a mound center continued after that important site was abandoned in the early A.D. 1300s (Story 2000). In cultural terms, the Pace McDonald site was likely occupied by a pre- historic Caddo group who was apparently related to others of similar socio-political character in the upper Neches, middle and upper Sabine, and the Angelina River basins (Perttula 2011). Whether it was a subsidiary or satellite to any other contemporaneous Caddo mound centers is not known. 


\section{SITE IMPRESSIONS FROM THE 2010 SURFACE COLLECTIONS}

Based on the surface collecting work, it is apparent that the main concentration of surface artifacts on the Sanford lands at the Pace McDonald site is in a ca. $150 \times 150 \mathrm{~m}$ area (5.5 acres) north of Mound No. 1, the mound owned by the Texas Historical Commission (Figure 2). This concentration apparently extends to the north and west off of the Sanford lands an unknown distance, but probably at least another $100+m$ to the west on the landform and towards Mound Prairie Creek (see Figure 1;
Thurmond 1978; Perttula 2011). Midden deposits have been previously noted in this same area, as well as a possible borrow pit depression (No. 5) (see Figure 1). The density of Caddo artifacts is very low in surface contexts east of Mound No. 1 and around Mound No. 2, as had been previously noted by Thurmond (1978).

Amidst the primary artifact concentration north and northeast of Mound No. 1 are three possible low mounds (see Figure 2), each about $40 \mathrm{~m}$ in diameter and $1 \mathrm{~m}$ in height. These possible mounds are approximately the same size as Mound No. 2 appears in 2010 , though it was estimated at only $18.3 \mathrm{~m}$ in

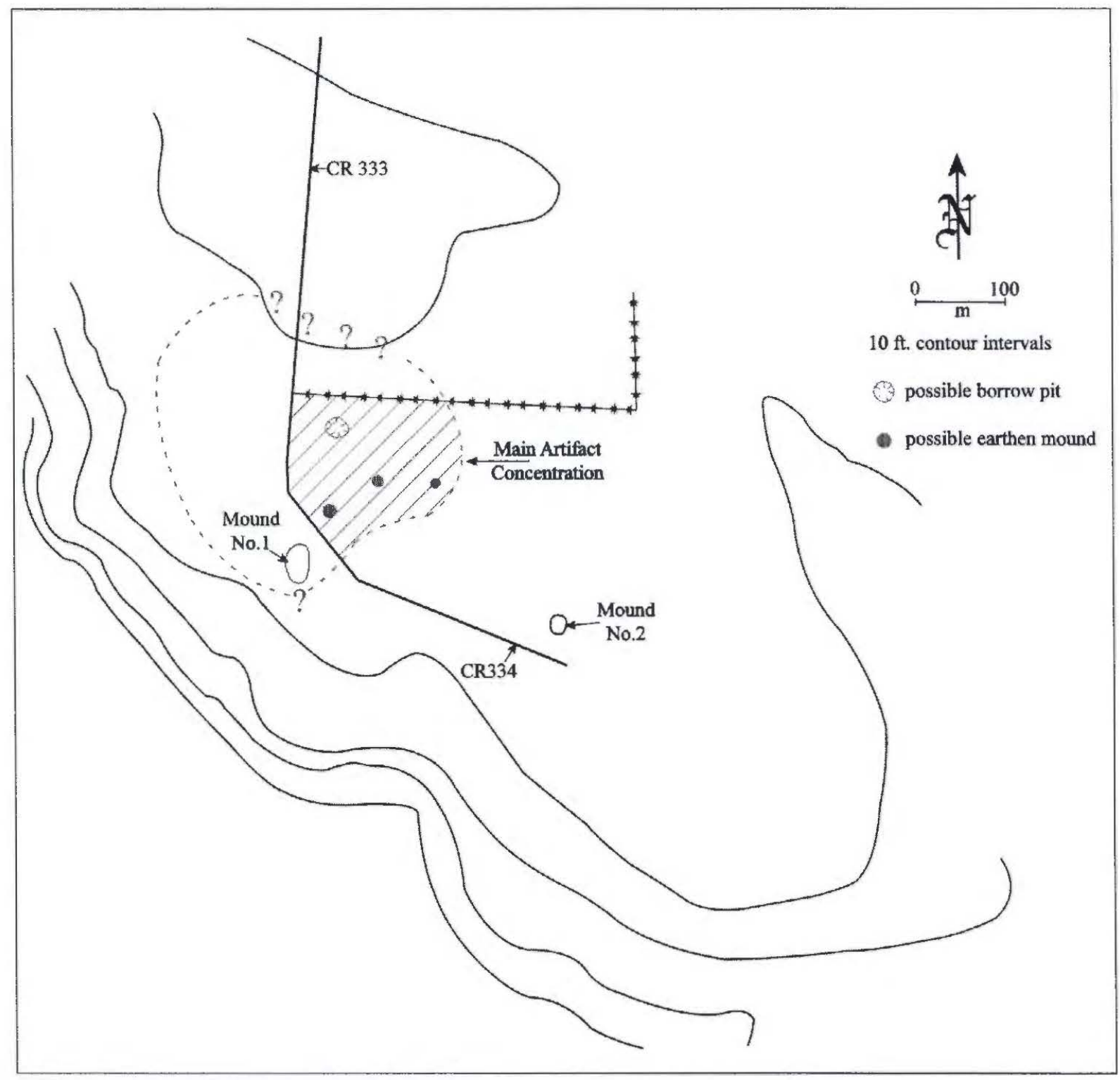

Figure 2. Visible features and artifact concentrations at the Pace McDonald site, April 2010. 
diameter in 1933 (Pearce and Jackson 1933). These mounds and possible mound features have been plowed down and spread out over the years.

\section{ARTIFACT ASSEMBLAGE FROM THE 2010 SURFACE COLLECTION}

The artifacts found in the 2010 surface collections at the Pace McDonald site are dominated by prehistoric Caddo ceramic shcrds and lithic debris (Table 1). There is only a limited range of other artifact categories represented in the surface collection asscmblage, including burned clay, chipped stone tools, animal bones, and a small assortment of 19 th ccntury Anglo-American artifacts.

Table 1. Artifacts recovered in the April 2010 surface collection at the Pace McDonald site.

\begin{tabular}{lcc}
\hline Artifact Category & No. & Percent \\
\hline Caddo Ceramic Sherds & 382 & 86.6 \\
Burned Clay pieces & 1 & 0.2 \\
Chipped Stone Tools & 2 & 0.5 \\
Prehistoric Lithic Debris & 42 & 9.5 \\
19th Century Historic Artifacts & 9 & 2.0 \\
Animal bones, burned & 5 & 1.1 \\
\hline Totals & 441 & 100.0 \\
\hline
\end{tabular}

\section{Ceramic Vessel Sherds}

Approximately $78 \%$ of the vessel sherds in the 2010 surface collection are from undecorated vessels or the undecorated portions of decorated vessels; $21.7 \%$ of the sherds, including both fine wares (engraved and red-slipped sherds) and utility wares (wet paste decorations), are decorated (Table 2). These proportions are almost identical to that documented in the larger assemblage of Caddo ceramic sherds in the TARL collection (Perttula 2011: Table 1).

The plain to decorated sherd ratio (P/DR) in this surface-collected assemblage is 3.60. The P/DR in the TARL collections from Pace McDonald is 3.43 (Perttula 2011), clearing indicating that both collections derive from the same prehistoric Caddo sherd sample, a sample with a high proportion of plain sherds, likely plain vessels, and/or vessels with
Table 2. The Caddo ceramic sherd assemblage in the $\mathbf{2 0 1 0}$ surface collection.

\begin{tabular}{lcc}
\hline Sherd Type & No. & Percent \\
\hline Plain rim & 7 & 1.8 \\
Plain body & 276 & 72.2 \\
Plain base & 16 & 4.2 \\
$\quad$ Subtotal, Plain sherds & 299 & 78.2 \\
& & \\
Decorated fine ware & 29 & 7.6 \\
Decorated utility ware & 54 & 14.1 \\
$\quad$ Subtotal, Decorated sherds & 83 & 21.7 \\
\hline Totals & 382 & 99.9 \\
\hline
\end{tabular}

decorations confined principally to the rim, rather than being decorated commonly on the vessel rim and body. Combining the TARL and 2010 surface collection assemblages ( $n=1357$ sherds), the P/DR at the Pace McDonald site is 3.48 (i.e., only about $22 \%$ of the sherds are decorated).

There are 13 rim sherds in the 2010 surface collection of vessel sherds. More than $53 \%$ are from plain ware vessels $(n=7)$; another $30.8 \%$ are from decorated fine ware vessels ( $n=4$, engraved vessels), and only $15.4 \%$ are from utility ware vessels. If we combine the TARL and 2010 surface collection sherds, the 52 rim sherds are distributed amongst the three wares as follows: plain ware $(n=22,42.3 \%)$; utility ware $(n=22$, $42.3 \%)$; and fine ware $(\mathrm{n}=8,15.4 \%)$.

In the 2010 surface collections from the Pace McDonald site, fine wares are well represented $(35 \%)$ in the decorated sherd sample (Table 3 ). Slightly more than half of the fine wares have engraved decorations, with the remainder comprised of red-slipped bottle and bowl/carinated bowl sherds. The combined TARL and 2010 sherd samples indicate that approximately $26 \%$ of the decorated sherds from the site are from fine warcs, with the fine wares divided into sherds that are engraved $(57 \%$ of the fine wares); engraved and red-slipped (1.3\%); and red-slipped $(41.8 \%)$.

The utility wares account for $65 \%$ of the 2010 surface collection decorated sherds, and $73.9 \%$ of the combined sherd samples (see Table 3). Sherds from vessels decorated with incised, tool punctated, fingernail punctated, and incised-punctated elements are the most popular in both collections, with $43 \%$ 
Table 3. Decorated sherds in the 2010 surface collection and TARL collections.

\begin{tabular}{|c|c|c|c|c|c|c|}
\hline \multirow{2}{*}{$\begin{array}{l}\text { Decorative } \\
\text { Method }\end{array}$} & \multicolumn{2}{|c|}{$\begin{array}{l}\text { TARL } \\
\text { Collections }\end{array}$} & \multicolumn{2}{|c|}{$\begin{array}{l}2010 \\
\text { Collections }\end{array}$} & \multicolumn{2}{|c|}{$\begin{array}{l}\text { Combined } \\
\text { Samples }\end{array}$} \\
\hline & $\mathrm{N}$ & Percent & $\mathrm{N}$ & Percent & $\mathrm{N}$ & $\%$ \\
\hline \multicolumn{7}{|l|}{ Fine Ware } \\
\hline Engraved & 29 & 13.2 & 16 & 19.3 & 45 & 14.9 \\
\hline Engraved-red slipped & 1 & 0.5 & - & 0.0 & 1 & 0.3 \\
\hline Red-slipped & 20 & 9.1 & 13 & 15.7 & 33 & 10.9 \\
\hline Subtotal & 50 & 22.6 & 29 & 35.0 & 79 & 26.1 \\
\hline \multicolumn{7}{|l|}{ Utility Ware } \\
\hline Incised & 74 & 33.6 & 22 & 26.5 & 96 & 31.7 \\
\hline Tool punctated & 37 & 16.8 & 11 & 13.3 & 48 & 15.9 \\
\hline Fingernail punctated & 24 & 10.9 & 11 & 13.3 & 35 & 11.6 \\
\hline Incised-punctated & 12 & $5.5^{*}$ & 6 & 7.2 & 18 & 5.9 \\
\hline Circular punctated & 8 & 3.6 & 1 & 1.2 & 9 & 3.0 \\
\hline Brushed & 5 & 2.3 & 2 & 2.4 & 7 & 2.3 \\
\hline Pinched & 4 & 1.8 & 1 & 1.2 & 5 & 1.7 \\
\hline Linear punctated & 3 & 1.3 & - & 0.0 & 3 & 1.0 \\
\hline Cane punctated & 1 & 0.5 & - & 0.0 & 1 & 0.3 \\
\hline Appliqued & 1 & 0.5 & - & 0.0 & 1 & 0.3 \\
\hline Appliqued-punctated & 1 & 0.5 & - & 0.0 & 1 & 0.3 \\
\hline Subtotal & 170 & 77.4 & 54 & 65.0 & 224 & 73.9 \\
\hline Totals & 220 & 100.0 & 83 & 100.0 & 303 & 100.0 \\
\hline
\end{tabular}

*There is also one vessel section comprised of 12 body sherds and one rim sherd; it is not included in the total number of decorated sherds.

of the utility ware sherds having incised designs (Figure 3d); 21\% are tool punctated (Figure 3b); $15.6 \%$ are fingernail punctated (Figure $3 \mathrm{c}$ ); and $8 \%$ have incised and punctated decorations. Less common utility ware sherds at the Pace McDonald site have circular punctated, brushed, pinched, linear punctated, cane punctated, and appliqued decorative elements (see Table 3); together these comprise 12\% of the utility ware sherds.

As with the TARL sherd sample from the Pace McDonald site (Perttula 2011:Table 3), red-slipped sherds from bottles (i.e., those with an exterior red slip) and carinated bowls/bowls are common in the fine ware sherds in the 2010 surface collection (Table 4). They comprise $44.8 \%$ of the fine wares in this small sherd assemblage. In East Texas, the manufacture and use of red-slipped pottery unembellished with engraved decorations is most commonly seen in Middle Caddo ceramic traditions, whether it be in
Caddo sites on the Red River or in parts of the upper Sulphur, Big Cypress, and Sabine River basins.

There are several different engraved decorative elements in the 2010 surface collection from Pace McDonald (see Table 4). Of those that have more than horizontal engraved lines (from Hickory Engraved vessels?), or just straight or parallel lines of uncertain orientation (see Figure $3 \mathrm{~g}$ ), this includes a diagonal engraved rim sherd (see Figure 3f), a body sherd with opposed engraved lines, and two bottle sherds with curvilinear engraved lines.

There is a possible post-A.D. 1400 rim sherd from a bowl or carinated bowl with a horizontal engraved line below the lip, and that has at least two small hatched triangles pendant from that line (see Figure 3c and Table 4). This decorative element is reminiscent of at least two varieties of Hume Engraved (see Suhm and Jelks 1962:Plate 42b-c; Perttula 2008:Figure 6-65f-g), particularly Hume 


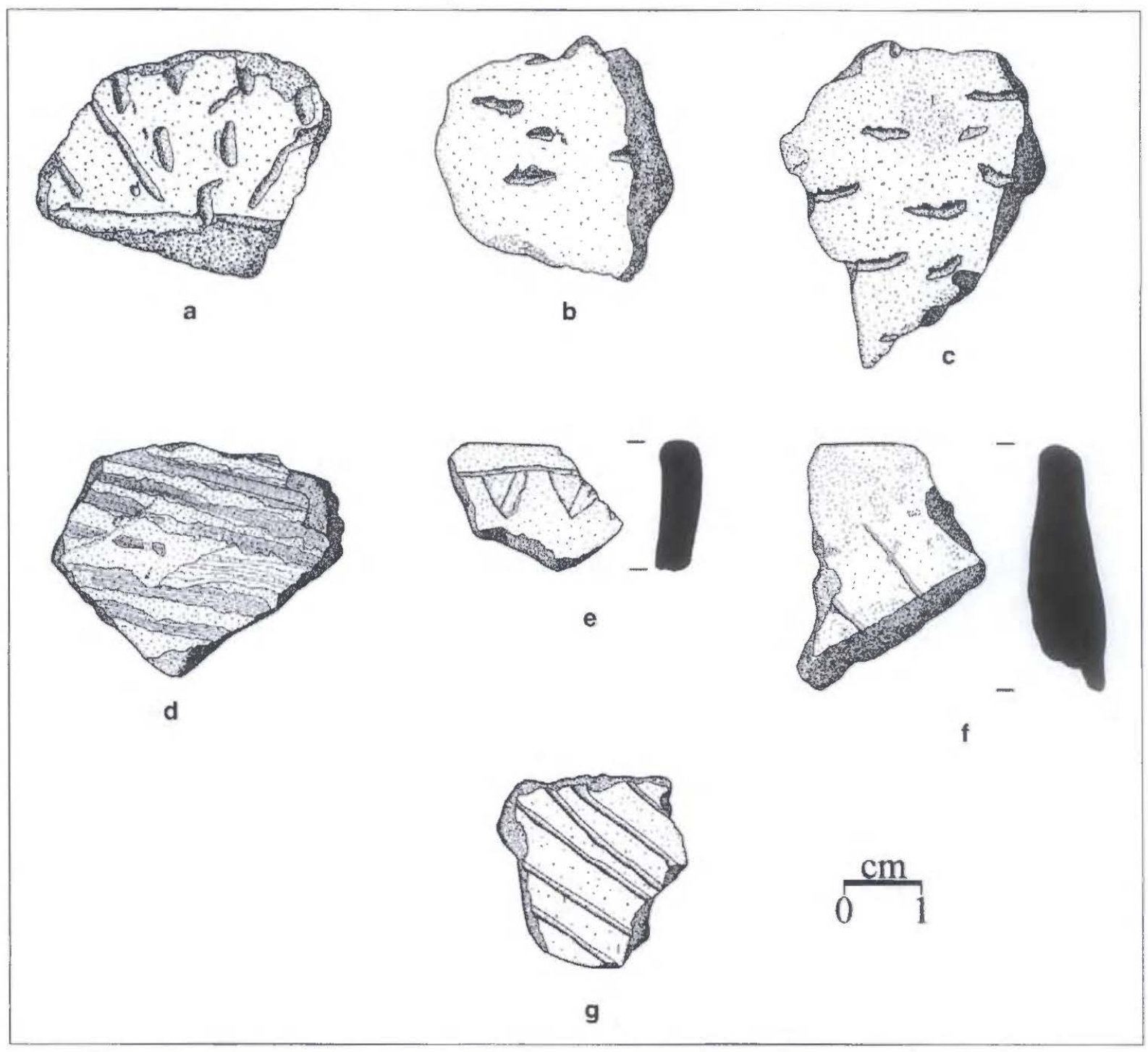

Figure 3. Selected decorated sherds from the Pace McDonald site: a, incised-punctated; $b$, tool punctated; $c$, fingernail punctated; d, broad parallel incised lines; e, hatched engraved triangles; f, diagonal engraved lines; g, parallel engraved lines.

Engraved, var. Allen, since this variety includes bowls rather than short-necked bottles. Poynor Engraved, var. $C$ (Perttula 2008:Figure 6-64) also has small hatched pendant triangles. If either of these variety identifications are reasonable, the occurrence of this sherd would suggest a very limited use of the Pace McDonald site in Frankston phase times, after ca. A.D. 1480-1560 (Perttula 2008:Table 6-37). A body sherd with parallel and several arcing engraved lines may be from a Poynor Engraved, var. Cook vessel (see Perttula 2008:Figure 6-63d). This particular variety of Poynor Engraved is common in ca. A.D. $1400-1560$ burial contexts in the upper Neches River basin (Perttula 2008: Table 6-37).
Absent in the engraved fine wares at the site are types such as Holly Fine Engraved or Spiro Engraved (Suhm and Jelks 1962). These fine ware engraved types are considered material culture hallmarks of the Early Caddo period (along with various decorated utility wares), and the Alto phase (e.g., Story 2000:14) in East Texas. Their absence at the Pace McDonald site may be indicative of the fact that the Caddo occupation here postdates the Early Caddo period.

The decorated utility ware sherds in the 2010 surface collection at the Pace McDonald site are dominated by sherds from vessels decorated with punctations ( $44.4 \%$ of the utility wares), incised 
Table 4. Decorative elements in the fine ware sherds.

\begin{tabular}{lcc}
\hline Decorative elements & No. & Percent \\
\hline Interior/exterior red slip & 5 & 17.2 \\
Exterior red slip & 8 & 27.6 \\
& & \\
Straight engraved line & 4 & 13.8 \\
Straight and opposed engraved lines & 1 & 3.4 \\
Diagonal engraved lines* & 1 & 3.4 \\
Horizontal engraved lines* & 2 & 6.9 \\
Horizontal engraved lines+ & 1 & 3.4 \\
Horizontal engraved line and hatched pendant triangles* & 1 & 3.4 \\
Opposed engraved lines & 1 & 3.4 \\
Parallel engraved lines, closely-spaced & 2 & 6.9 \\
Parallel and arcing engraved lines & 1 & 3.4 \\
Curvilinear engraved lines** & 2 & 6.9 \\
\hline Total & 29 & 100.0 \\
\hline
\end{tabular}

*rim sherds; **bottle sherds; +=carinated bowl sherd

lines $(40.7 \%)$, and sherds from vessels decorated with incised-punctated elements $(9.3 \%)$ (Table 5). Minor decorative methods documented in the site's utility wares are brushed $(3.7 \%)$ and pinched $(1.9 \%)$ categories. These proportions for each decorative methods/elements categories are not significantly different than the utility ware assemblage in the TARL collections from the site (Perttula 2011:Table 4).

The punctated sherds from the site are comprised of a mixture of tool ( $46 \%$ of the punctated sherds), fingernail (46\%), circular (4\%), and crescent-shaped (4\%) punetated elements (see Table 5). There are no punctated rim sherds, suggesting that the bodics of many utility ware vessels are decorated with punctations; the decoration on the rims of these vesscls was probably not punctated, but more likely had incised decorative elements (cf. Dunkin Incised or Weches Fingernail Impressed), typical of Caddo utility wares that have different rim and body decorations. There is one Weches Fingernail Impressed, var. Alto body sherd (see Stokes and Woodring 1981:185-186 and Figures 22m and 23bc) in the assemblage. This particular sherd has rows of crescent-shaped punctations.

Among the incised utility wares in the 2010 surface collection, there are sherds with widely-spaced cross-hatehed lines (likely either from Canton Incised or Dunkin Incised vessels), opposed incised lines (also probably from Canton Incised or Dunkin
Incised vessels), parallel or straight incised lines of uncertain orientation (possibly body decorative treatments), diagonal (a rim sherd), and horizontaldiagonal and opposed incised lines on another vessel rim (see Table 5). Thesc incised sherds may be from Davis Incised, Dunkin Incised, or Canton Incised vessels, or from other Caddo ceramic types with incised elements that have not been typologically identified to date in the region.

The incised-punctated sherds in the 2010 surface collection sample from the Pace McDonald sitc have opposed or opposed diagonal incised lines with associated tool punctated zones (likely bclow the incised decorative element) or triangular zones filled with tool punctations (see Figure 3a). These utility wares are likely from Canton Incised and Pennington Punctated-Incised vessels. Other sherds have a zone of punctations adjacent to simple geometric incised elements, with the punctated elements apparently limitcd to the body of the vessel and the incised elements restricted to the rim.

A distinctive characteristic of the Pace McDonald utility wares is the occurrence of sherds from brushed and pinched jars, but only in low frequencies (see Table 4). These two categories of decorated utility wares together comprise only $5.6 \%$ of the assemblage. They apparently represent different means of rim and/or body decoration on jars, with parallel (likely vertical) or curvilinear brushing on 
Table 5. Decorative elements in the utility ware sherds.

\begin{tabular}{lcc}
\hline Decorative methods and elements & No. & Percent \\
\hline Brushed, parallel & 1 & 1.9 \\
Brushed, curvilincar & 1 & 1.9 \\
$\quad$ Subtotal, brushed & 2 & 3.7 \\
Cross-hatched incised lines & 1 & 1.9 \\
Diagonal incised lines* & 1 & 1.9 \\
Horizontal, diagonal, and opposed incised lines* & 1 & 1.9 \\
Opposed incised lines & 1 & 1.9 \\
Parallel incised lines & 8 & 14.8 \\
Single straight incised line & 4 & 7.4 \\
Straight incised line, broad line & 6 & 11.1 \\
$\quad$ Subtotal, incised & 22 & 40.7 \\
Vertical pinched ridges & & 1.9 \\
$\quad$ Subtotal, pinched & 1 & 1.9 \\
Circular punctated rows & 1 & 1.9 \\
Fingernail punctated rows/zone & & 7.4 \\
Fingernail punctated, single & 1 & 13.0 \\
Tool punctated rows/zone & 4 & 9.3 \\
Tool punctated, single & 7 & 11.1 \\
Weches Fingernail linpressed, var. Alto & 5 & 1.9 \\
$\quad$ Subtotal, punctated & 6 & 44.4 \\
Opposed incised lines and tool punctated zone & 1 & 1.9 \\
Opposed diagonal incised lines and tool punctated-filled triangles+ & 1 & 5.6 \\
Straight incised line adjacent to zone of tool punctates & 3 & 9.3 \\
\hline Totals & 5 & \\
\hline & & \\
\hline
\end{tabular}

*rim sherd; +=carinated bowl sherd

jar bodies and vertical pinched rows on both the rim and body of jars. The pinched jar sherd may be from a Killough Pinched vessel (see Suhm and Jelks 1962: Platc 46f).

The very low frequency of brushed pottery at the Pace McDonald site is notable. Brushed utility wares like Bullard Brushed account for at least 50$80 \%$ of all the decorated sherds in upper Neches River basin Frankston phase (ca. A.D. 1400-1650) assemblages (Perttula 2008:Table 6-38), making it clear that Pace McDonald was likely not occupied in the Frankston phase. It was only by the early 15th century A.D. that "Caddo potters in the upper Neches River basin began to manufacturc considerable numbers of jars with brushed vessel bodies and rims" (Pertula 2008:6-247).

The vast majority of ceramic vessel sherds from the site, whether in the TARL collections or the 2010 surface collections, are from vessels tempered with grog (i.e., fired and crushed clay), occasionally in association with other tempers (such as hematite or bone). This is the principal prehistoric Caddo ceramic practice in the upper Neches River valley (see Perttula 2008:Figure 6-70). More than $13.9 \%$ of the sherds do have crushed 
Table 6. Use of bone temper in the Pace McDonald Caddo ceramic sherds, TARL collections and 2010 surface collections.

\begin{tabular}{|c|c|c|c|c|}
\hline Ware & No. & Percent & $\begin{array}{l}\text { No. with } \\
\text { bone temper }\end{array}$ & $\begin{array}{l}\text { Percent of total bue-teaperd } \\
\text { sherd sample }\end{array}$ \\
\hline Plain Ware & 1054 & 77.4 & 153 & 11.2 \\
\hline Fine ware & 79 & 5.8 & 5 & 3.70 .4 \\
\hline Utility ware & 229 & 16.8 & 33 & $24 x \quad 2.4$ \\
\hline Totals & 1362 & 100.0 & 1981 & 13.9 \\
\hline
\end{tabular}

and burned bone temper added to the clay paste (Table 6). Proportionally, bone temper is used most frequently in the plain wares and utility wares, about twice as frequently as is the case for the fine wares.

\section{Burned Clay}

Only a single piece of burned clay is in the 2010 surface collection. This piece is a product of a localized burning event at the site where a piece of clay was hardened through exposure to fire, perhaps an earth oven or hearth.

\section{Chipped Stone Tools}

The first chipped stone tool in the 2010 surface collections is an Alba point made from a non-local grayish-brown chert (Figure 4). This point has a parallel stem and a flat base, is bifacially chipped, and reworked on the tip (probably after it was broken during its first use after knapping). It is $20.1 \mathrm{~mm}$ in length, $15.0 \mathrm{~mm}$ in width, $2.9 \mathrm{~mm}$ in thickness, and it has a stem width of $4.3 \mathrm{~mm}$. Alba points are gencrally considered Formative to Early Caddo period (ca. A.D. 800-1200) arrow points, although because they are diagnostic of the Alto phase (Story 2000), they may date from as long a period of manufacture and use as ca. A.D. 850-1300. They are particularly well-represented at the George C. Davis site on the Neches River (Newell and Krieger 1949:161 and Figure 56a-h), where they are considered the only "resident type." In the TARL collections from Pace McDonald, 55\% of the arrow points are of the Alba type (Perttula 2011:Table 6).

The second chipped stone tool is a graver/unilateral retouched flake. It is made from a non-local gray chert.

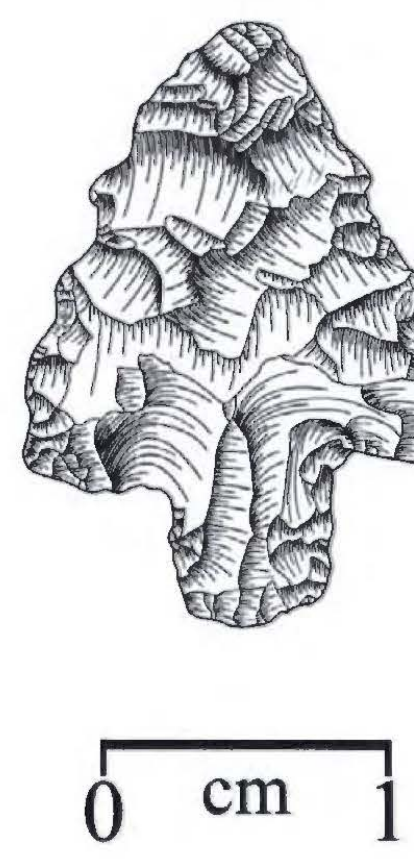

Figure 4. Alba arrow point from the 2010 surface collections at the Pace McDonald sitc. Illustration by Lance Trask.

\section{Lithic Debris}

The lithic debris from the Pace McDonald site in the 2010 surface collection $(n=42)$ are predominantly pieces of non-local cherts that are apparently from the Edwards Plateau region of Central Texas, or from Brazos River and Trinity River stream gravels (Table 7); $86 \%$ of the lithic debris are made from these materials. The one piece of white novaculite lithic debris is from a southeastern Oklahoma Ouachita Mountains source 
Table 7. Lithic debris from the $\mathbf{2 0 1 0}$ surface collection at the Pace McDonald site.

\begin{tabular}{lccc}
\hline Raw Material & Cortical & Non-Cortical & N \\
\hline Non-local chert & & 2 & 6 \\
dark gray chert & 4 & 14 & 21 \\
gray chert & 7 & 1 & 1 \\
gray chert with black inclusions & 1 & - & 1 \\
grayish-brown chert & - & 1 & 1 \\
brown-dark brown banded chert & 1 & 2 & 1 \\
black chert & - & 1 & 2 \\
white chert & - & - & 2 \\
white-black chert & 1 & 21 & 1 \\
white novaculite & 1 & & 36 \\
\multicolumn{1}{c}{ Subtotal } & 15 & & 1 \\
Local lithic raw materials & & - & 3 \\
yellow chalcedony & 1 & 1 & 1 \\
brown chert & 3 & 1 & 1 \\
yellow chert & - & 2 & 6 \\
quartzite & - & 23 & 42 \\
\hline \multicolumn{1}{l}{ Subtotal } & 4 & & \\
\hline Totals & 19 & & \\
\hline
\end{tabular}

or a Red River gravel source. The Caddo knappers that lived at the site clearly had a broad range of lithic raw materials to draw upon, including ready access to non-local chert, Ouachita Mountains chert, and local (14\%) chalcedony, earth-colored cherts, and quartzite. Other local lithic raw matcrials noted in the Pace McDonald lithic debris includes petrified wood and hematite (Perttula 2011:Table 10).

Cortical pieces-including both stream-rolled, roughened, and with a limestone-covered cortcxcomprise $45 \%$ of all the lithic debris, including $42 \%$ of the non-local cherts and $67 \%$ of the local lithic raw materials (see Table 7). The high proportion of cortical flakes suggests that thesc lithic raw materials were brought to the site with significant amounts of cortex remaining on them (perhaps as pebbles), and knapped on-site; less likely is the possibility that both non-local and local lithic raw materials were brought to the site as tools or near-complete tools with cortical remnants (or even as large flakes with cortical remnants).

\section{9th Century Artifacts}

The historic artifacts in the 2010 surface collection were found in an area about $100-150 \mathrm{~m}$ northeast of Mound No. 1 (see Figure 2). These few artifacts are domestic/kitchen and architectural in character, and include a cut nail (1820-1891, see Wells 2000), a plain ironstone body sherd (post-1850s), a ca. post-1870s (sec Greer 1981) stoneware base sherd with a clear exterior glaze, and a bluc flown blue body sherd. Flown blue vessels became popular in the United States in the 1840s-1850s (Samford 2000:79). Overall, the few historic artifacts from the Pace McDonald site suggest there may have been a mid- to late 19th century settlement/farmstead on one part of the 2010 surface collection area.

\section{Animal Bone}

Five small pieces of poorly preserved burned animal bone were recovered in the 2010 surface 
collections. They may be refuse from prehistoric Caddo midden deposits or other areas of concentrated trash disposal at the site.

\section{SUMMARY}

In April 2010, we were able to conduct a surface collection after a recent disking over a substantial portion of the known extent of the Pace McDonald site, a prehistoric Caddo mound center in the upper Neches River basin that may have been occupied from ca. A.D. 1100-1400 (Perttula 2011). During the course of the surface collection, one substantial artifact concentration was identified in an arca just north of Mound No. 1, the larger of the two known mounds at the site. This area contained numerous Caddo ceramic vessel sherds, and much lesser amounts of chipped stone tools, lithic debris, burned clay, animal bone, and mid- to late 19th century ceramics and a cut nail. In this same area are three small and low rises that may be additional earthen mounds (see Figure 2); they have yet to be examined through shovel testing, coring, or any kind of excavations.

The eastem part of the Pace McDonald site (in the general vicinity of Mound No. 2) appears to have a very low density of prehistoric Caddo artifacts, as was previously noted by Thurmond (1978). This area of the mound center may not have been a locale for domestic habitation during the Early to Middle Caddo period occupation.

The surface collection-recovered artifacts from the site are very much the same in character and relative proportions as the larger sample of artifacts from the Pace McDonald site in the TARL collections (from both mound excavations and disparate surface collections). This indicates that the construction and use of the mounds was contemporaneous with the occupation of non-mound habitation areas.

The ceramic vessel sherds in the 2010 surface collection are predominantly grog-tempered, and plain ware vessels are particularly common (based on a P/DR ratio of 3.60 and a relatively high proportion of plain rims); sherds from decorated utility ware vessels outnumber fine wares about 3:1. In the utility wares, decorative elements consist primarily of simple geometric patterns of incised lines and incisedpunctated designs (usually featuring diagonal opposed incised lines and triangles filled with tool punctations), rows and/or zones of tool, fingernail, and circular punctations; brushed and pinched sherds are a minor aspect of the utility wares at Pace McDonald. The fine wares include engraved (i.e., geometric elements, hatched and cross-hatched elements, mainly triangles, and carinated bowls and bottles) and red-slipped fine wares. Finally, the lithic artifacts found in the 2010 surface collection also indicate the manufacture and use of chipped stone tools made from non-local cherts.

\section{ACKNOWLEDGEMENTS}

We want to especially thank Mr. Johnny Sanford for granting us permission to work on his land, and allowing us to gather the April 2010 surface collection. The artifacts from this work have been returned to him following their study. Thanks also to Lance Trask for preparing map and artifact figures, and to Sandy Hannum for also preparing map figures for this article.

\section{REFERENCES CITED}

Coffee, D. R.

1975 Soil Survey of Anderson County. Texas. United States Department of Agriculture. Soil Conservation Service, in cooperation with the Texas Agricultural Experiment Station.

Diggs Jr., G. M., B. L. Lipscomb, M. D. Reed and R. J. O'Kennon

2006 Illustrated Flora of East Texas, Volume One: Introduction, Pteridophytes, Gymnosperms, and Monocotyledons. Sida, Botanical Miscellany, No. 26. Botanical Research Institute of Texas, Fort Wortb.

Greer, G. H.

1981 American Stoneware: The Art and Craft of Utilitarian Pottery. Schiffer Publishing Ltd., Exton, Pennsylvania.

Newell, H. P. and A. D. Krieger

1949 The George C. Davis Site, Cherokee County, Texas. Memoirs No. 5. Society for American Archaeology, Menasha, Wisconsin.

Pearce, J. E. and A. T. Jackson

1933 Royal Place or Pace McDonald Place, Large Earth Mound and Ash Mound located on Mound Prairie or Wells Creek, $3 / 4$ Mile N. of S.W. from Old Mound Prairie Village, and 9 Miles N.E. of Palestine, Anderson County, Texas, Tested by Digging a Large Shaft in No. 1 and Trenching and Test Holes in No. 2, September 7 to September 9, 1933. MS on file, Texas Archeological Research Laboratory, The University of Texas at Austin. 
Perttula, T. K.

2008 The Ceramic Artifacts from the Lang Pasture Site (41AN38) and the Place of the Site within an Upper Neches River Basin Caddo Ceramic Tradition. In Archeological Investigations at the Lang Pasture Site (41AN38) in the Upper Neches River Basin of East Texas, assembled and edited by T. K. Pertula and D. B. Kelley, pp. 6-1 to 6-260. MS un file, Coastal Environments, Inc., Baton Rouge and Texas Department of Transportation, Environmental Affairs Division, Austin.

2011 Analysis of the Prehistoric Artifacts from the Pace McDonald Site (41AN51), Anderson County, Texas. Journal of Northeast Texas Archaeology 34:35-54.

Samford, P. M.

2000 Response to a Market: Dating English Underglaze Transfer-Printed Wares. In Approaches to Material Culture Research for Historical Archueologists, compiled by D. R. Brauner, pp. 56-85. 2nd Edition. The Society for Historical Archaeology, California, Pennsylvania.
Story, D. A.

2000 Introduction. In The George C. Davis Site, Cherokee County, Texas, by H. Perry Newell and Alex D. Krieger, pp. 1-31. 2nd Edition. Society for American Archateology, Washington, D.C.

Thurmond, J. P.

1978 The Pace McDonald Site: A Caddoan Mound Center in Anderson County, Texas. MS on file, Texas Archeological Research Laboratory. The University of Texas at Austin.

Wells, T.

2000 Nail Chronology: The Use of Technologically Derived Features. In Approaches to Material Culture Research for Historical Archaeologists, compiled by D. R. Brauner, pp. 318-339. 2nd Edition. The Society for Historical Archaeology, California, Pennsylvania. 